\title{
地質・土袞・土地利用の空間分布 を考慮した水循環解析手法の検討 HYDROLOGICAL MODEL ANALYSIS CONSIDERING SPATIAL DISTRIBUTION OF GEOLOGICAL, SOIL AND LAND USE CONDITIONS
}

\author{
木内豪 1 - 渡部康実 ${ }^{2}$ \\ Tsuyoshi KINOUCHI and Yasumi WATANABE \\ 1正会員 博(工) 東京工業大学総合理工学研究科環境理工学創造専攻 (广226-8503 横浜市緑区長津田町4259) \\ 2正会員 国土交通省東北地方整備局八戸港湾・空港整備事務所（广031-0071 八戸市沼館4-3-19）
}

\begin{abstract}
Physically distributed modeling is highly required for hydrological prediction in watersheds with heterogeneous land surfaces, soils and aquifers under uneven distribution of rainfall to better estimate impacts of future environmental changes such as land cover alterations and climate change. In this study, the applicability of WEP model, a grid-based distributed hydrological model, was enhanced by focusing on the hydrological influence of soil types, geological condition, land use, and their spatial distributions. The methodology to consider these factors in model inputs is established with the use of dataset of soil properties and geological conditions of the Abukuma river watershed. Simulation results showed good agreements with observed for most sub-watersheds followed by a certain parameter calibration, suggesting the potentially high applicability to a variety of watershed conditions.
\end{abstract}

Key Words : Hydrogeology, Soil properties, Land use, Spatial distribution, WEP model

\section{1.はじめに}

水資源の質や量の確保や洪水被害の軽減、さらには河 川における環境の保全を図る上での包括的・基本的概念 である “水循環の健全化”を現実の流域において具体化 させるには、現状抱える課題の分析や将来の水循環の変 化予測と望ましい水循環系の目標設定を行い、この目標 に対して有効な改善策、保全策をとる必要がある。

このため、将来の流域環境变化の影響予測や具体的施 策・保全策の影響・効果を精度よく定量化する手法が必 要となるが、流域面積の広い一級河川流域等では、土地 利用、地形、地質、気候条件が不均一で人間活動の影響 も大きくなるため、水循環を解析する数值モデル上でこ れらの条件を考慮した上で、流域環境変化の影響をより 高い信頼性で予測する必要が生じる。分布型のモデルは このような目的に適したモデルであるが、パラメータの スケール依存性の問題に対処する必要がある1)とともに、 地質・土壤・土地利用・気候特性の空間的な不均一性を 考慮して解析するモデル手法やモデルパラメータの与え 方に関する検討も十分行わなければならないと考える。

そこで、本論文では後者の課題を取り上げ、治水上も 水環境・水資源の面からも健全性の確保が求められ、流 域の多様な環境条件を反映した将来の水循環予測が必要
な阿武隈川流域の支川流域において、地質・土壌・土地 利用特性の異なる流域でできるだけ統一的に水循環解析 を行う手法の提示と適用性検討を行った結果を紹介する。

\section{2. 阿武噮川流域の概要と水循環の特徵}

\section{（1）流域の概要}

阿武隈川流域は福島県中通り地方から宮城県南部に至 る地域の都市活動、文化、自然環境の基盤を為し、流域 内に約 140 万人が居住する。流域面積は約 $5,400 \mathrm{~km}^{2}$ で、 国土数值情報に基づく土地利用は森林 $56 \%$ 、水田 $16 \%$ 、 烟 $14 \%$ 、建物用地 - 幹線交通用地 $7 \%$ 、荒地 - 内水地 その他7\%である(図-1)。本流域西側には奥羽山脈が南北 に走り地形が急峻で地質は火山噴出物からなるため、支 川が多量の土砂を流出して山麓地帯に扇状地を形成し、 洪積層、沖積層が発達している。本川の東側は花崗岩質 の阿武隈山地丘陵からなり、比較的緩勾配の支川が本川 に流れ込さ。これらの間の阿武隈川本川沿い平野には郡 山市、福島市、白河市、須賀川市などの都市が連続的に 位置し、様々な都市基盤・農地等が広がっている。

\section{（2）水循環 - 流況の特徵}

流域の年平均降水量はおよそ1,100～1,500mmで、平 野部から阿武隈山地はおよそ $1,200 \mathrm{~mm}$ 、奥羽山脈側では 


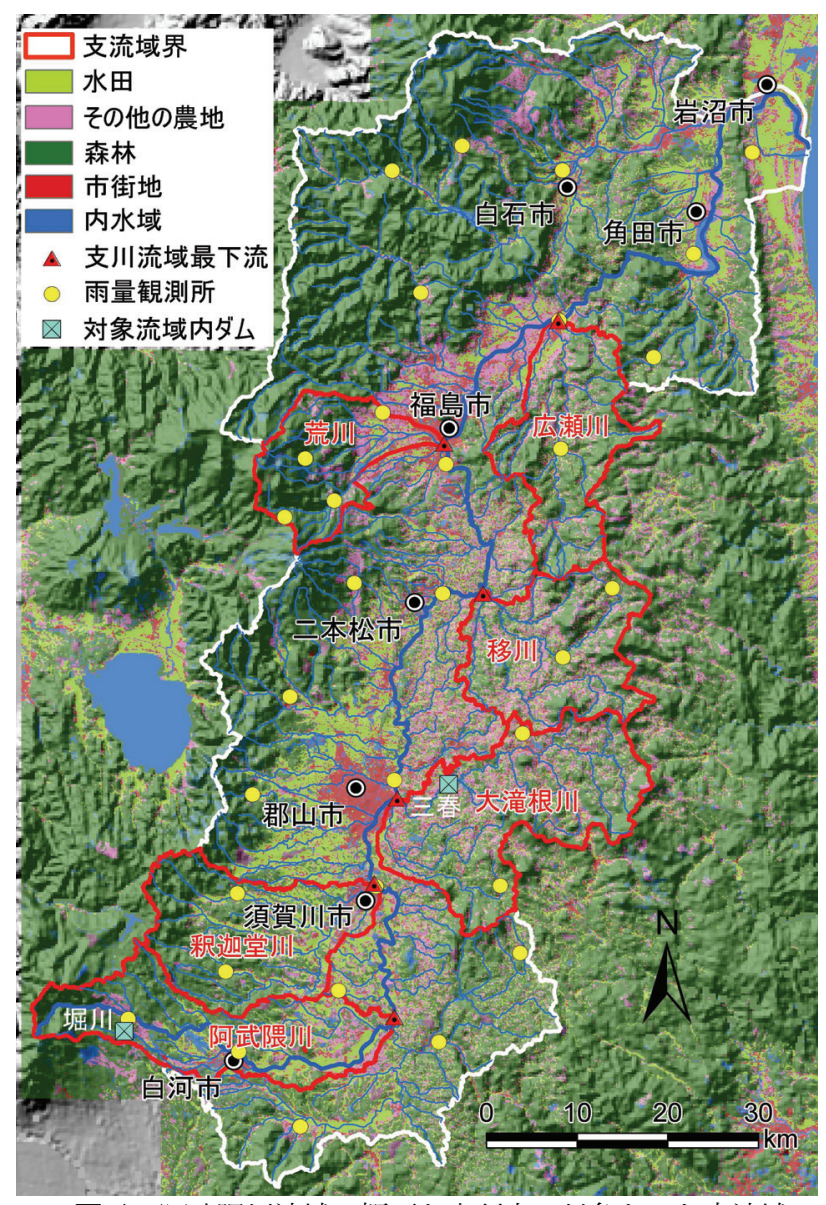

図-1 阿武隈川流域の概要と本研究で対象とした支流域

(白線：流域界、赤字：支流域名、黒丸：市庁舎位置)

急峻な地形のため $1,500 \mathrm{~mm}$ 程度であり、降雨・降雪とも に東側より多い2）。中流域平野部の灌泊農業は、流域内 の水源の他、奥羽山脈より西側の猪苗代湖や羽鳥湖から の取水（前者で最大約 $15 \mathrm{~m}^{3} / \mathrm{s}$ ) と安積疏水などによる導 水で支えられている。

前述のように本流域の地質は阿武隈川本川を挟んで西 側に新第三紀、第四紀の火山性地質等が複雑に分布する 一方、東側の阿武隈山地には花崗岩類が広がる。日本の 山地河川流域(面積数十 $\mathrm{km}^{2}$ 数百 $\mathrm{km}^{2}$ )を対象とした分析 ${ }^{3)}$ によると地質区分は低水流量や年最大流量といった流況 を左右する重要な因子であることから、地質区分が異な る阿武隈川の支川流域でもこのような特徵が見られるか 確認した(図-2)。なお、降水量の違いの影響をできるだ け取り除くため、比流量を降水量で正規化した。また、 降水量には各流域内の降水量測定地点の計測值の単純平 均を用いた。広瀬川で他より低い值を示す一方、同じく 東側に位置する移川では西側の釈迦堂川や阿武隈川上流 と同程度か、それ以上の值を示す。広瀬川流域では森林 の占める割合が高いため蒸発散量が多くなること、移川 では花崗岩の占める割合が高いこと等が要因として挙げ られる。荒川はいずれの流況指標でも最大となっており、 流域のほとんどが透水性の高い火山岩地質からなってい ることや急峻な地形が影響しているものと考えられる。

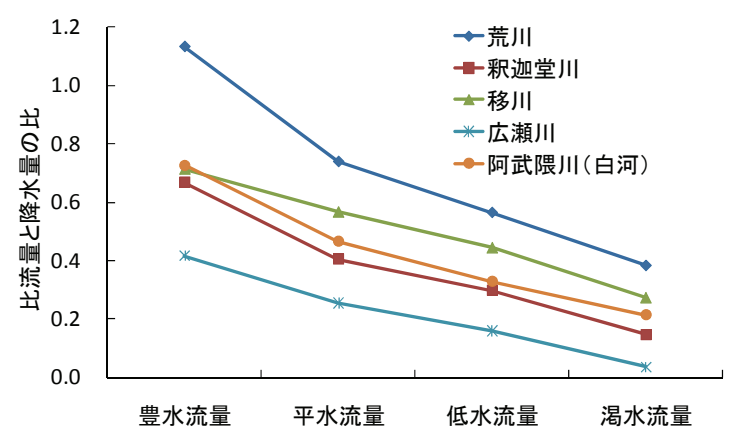

図-2 年降水量に対する比流量の比（1990-2004年平均)

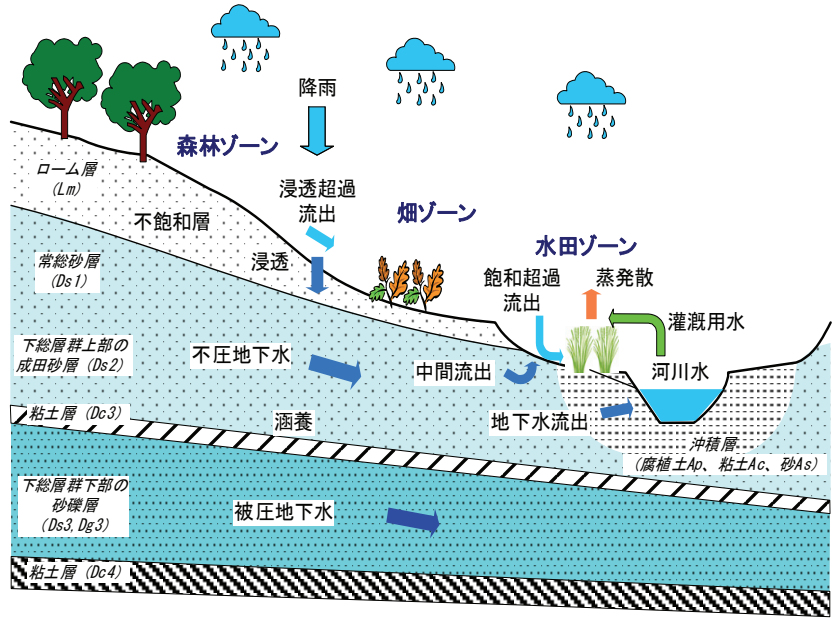

図-3 モデルで考慮されている素過程の概念図 （より詳細の説明は文献 4,5 に記載）

\section{3. 流域水循環特性の解析モデル}

\section{(1) 概要}

流域の流出特性の違いは支流域ごとの地質、土地利用、 土壌、地形、気候、人間活動の違いが複合された結果で ある。このような流域ごとの環境条件の違いを考慮した 水循環解析を行うため、本研究では水循環の様々な素過 程を物理方程式に基づき表現した分布物理型モデルとし てWEP MODELを用いた。WEPモデルは複雑な土地利 用を有する河川流域における水循環の定量化を目的とし た分布物理型の水循環モデルで、降雨流出過程の追跡計 算、不圧/被圧地下水の二次元地下水解析、河川水之地 下水の相互作用の考慮、浸透施設・調節池の効果の計算 及び水田の詳細計算などの機能を備えている(図-3)。国 内外流域における検証を通じて、都市域ばかりでなく水 田や畑地などが混在する流域一の適用性が確認されてき $た^{4,5)}$ 。

WEPモデルの駆動には流域や気象の条件に関する 様々な入力データが必要となる。今回作成した入力デー タのうち、主なものを表-1に示す。標高や地質などの空 間情報は平面直交座標系上で $500 \mathrm{~m} \times 500 \mathrm{~m}$ のメッシュ データに変換して用いた。また、流域の土地利用情報 (表-1)は、各土地利用における土地被覆の状態を水面、 水田、背の高い植生、背の低い植生、裸地、不浸透域 (建物、非建物)の6種類に再分類して用いる（表-2） ${ }^{5}$ 。 


\begin{tabular}{|c|c|}
\hline データ項目 & データソース \\
\hline 流域界・支流域界 & 国土数值情報 \\
\hline 標高 & 数值地図 $250 \mathrm{~m}$ メッシュ標高 \\
\hline 土地利用 & 国土数值情報(1/10細分区画) \\
\hline 表層土壌、表層地質 & 国土数值情報(1kmメッシュ) \\
\hline 河川流路 & 国土数值情報、数值地図 25000 \\
\hline 河川諸元 & 国土交通省、福島県 \\
\hline 人口 & 地域メッシュ統計(12年国勢調査) \\
\hline 利水情報 & 国土交通省・安積疏水土地改良区 \\
\hline 気温·日照時間·風速 & AMeDAS (計12地点) \\
\hline 雨量 & 国土交通省、AMeDAS (計32地点) \\
\hline 相対湿度 & 管区気象台等(計3地点) \\
\hline
\end{tabular}

表-2 主な土地利用分類別の各土地被覆割合と不浸透域の割合

\begin{tabular}{|c|c|c|c|c|c|c|c|}
\hline \multirow{3}{*}{ 土地利用分類 } & \multicolumn{7}{|c|}{ WEPの土地被覆分類 } \\
\hline & \multirow[b]{2}{*}{ 水域 } & \multicolumn{4}{|c|}{ 浸透域中の各分類の割合 } & \multicolumn{2}{|c|}{$\begin{array}{l}\text { 不浸透域の } \\
\text { 占內る割合 }\end{array}$} \\
\hline & & 水田 & $\begin{array}{c}\text { 高い植 } \\
\text { 生域 }\end{array}$ & $\begin{array}{l}\text { 低W } \\
\text { 植生域 }\end{array}$ & 裸地 & & $\begin{array}{l}\text { 建物域 } \\
\text { の割合 }\end{array}$ \\
\hline 山林 & 0 & 0 & 0.8 & 0.2 & 0 & 0 & 0 \\
\hline 水田 & 0 & 1 & 0 & 0 & 0 & 0 & 0 \\
\hline 畑など & 0 & 0 & 0.2 & 0.8 & 0 & 0 & 0 \\
\hline 建物用地 & 0 & 0 & 0.2 & 0.3 & 0.5 & 0.6 & 0.36 \\
\hline 道路 & 0 & 0 & 0 & 1 & 0 & 1 & 0 \\
\hline 公園・緑地 & 0 & 0 & 0.3 & 0.5 & 0.2 & 0.1 & 0.36 \\
\hline 河川・湖沼 & 0.5 & 0 & 0 & 1 & 0 & 0 & 0 \\
\hline
\end{tabular}

\section{（2）土壤の透水性と水分保持特性のモデル化}

森林土壌が多くを占める阿武隈川流域にあっては、表 層土壤の透水性・土㙵厚さや表層土壤下の基岩の透水性 が水循環現象に大きな影響を及ぼすものと考えられる。 WEPモデルでは表層土壌中における雨水の鉛直不飽和浸 透現象と表層土壌以深の帯水層中の地下水流動のモデル によってこのような山地域での水循環現象を考慮してい る(図-3, 5)ものの、土壤・帯水層に関する物理特性や空 間分布の情報をどのように与えるかが課題となる。

モデル上で土壌の物理特性の空間分布を考慮するため、 土袞の物性試験を行って土袞分類や地質分類との対応を 調べた。物性試験には流域内の12箇所で $100 \mathrm{~cm}^{3}$ の円筒容 器に採取した不擾乱土壤を用い、飽和透水係数、空隙率 及び間隙圧と水分量の関係（不飽和水分特性）を調べた。

図-4は各採取土袞の不飽和水分特性の実験結果及び Havercamp式(式1)に当てはめて同定した不飽和水分特性 曲線（黒の実線）を示す。

$$
\theta=\frac{\alpha\left(\theta_{s}-\theta_{r}\right)}{\alpha+\psi^{\beta}}+\theta_{r}
$$

ここで、 $\theta:$ 体積含水率 $\left(\mathrm{cm}^{3} / \mathrm{cm}^{3}\right) 、 \theta_{s}$ : 飽和水分量 $\left(\mathrm{cm}^{3} /\right.$ $\left.\mathrm{cm}^{3}\right) 、 \theta_{r}$ : 残留水分量 $\left(\mathrm{cm}^{3} / \mathrm{cm}^{3}\right) 、 \psi$ : 吸引圧 $\left(\mathrm{cm} / \mathrm{H}_{2} \mathrm{O}\right)$ 、 $\alpha, \beta$ : 定数である。図-4の上段はいずれも阿武隈川本川 より西側に位置する地点の土㙵であるが、縦軸を対数表 示した時、 $\psi$ と土壤水分量の関係が直線に近い傾向にあ る。このような特徵は一般的に団粒状構造を有する土畩 で見られる。。中段はいずれも阿武隈山地で採取した土 壤の結果で、細粒状構造を有する比較的粗孔隙の多い土 壤で見られる曲線を示す。下段は阿武隈川西側及び郡山
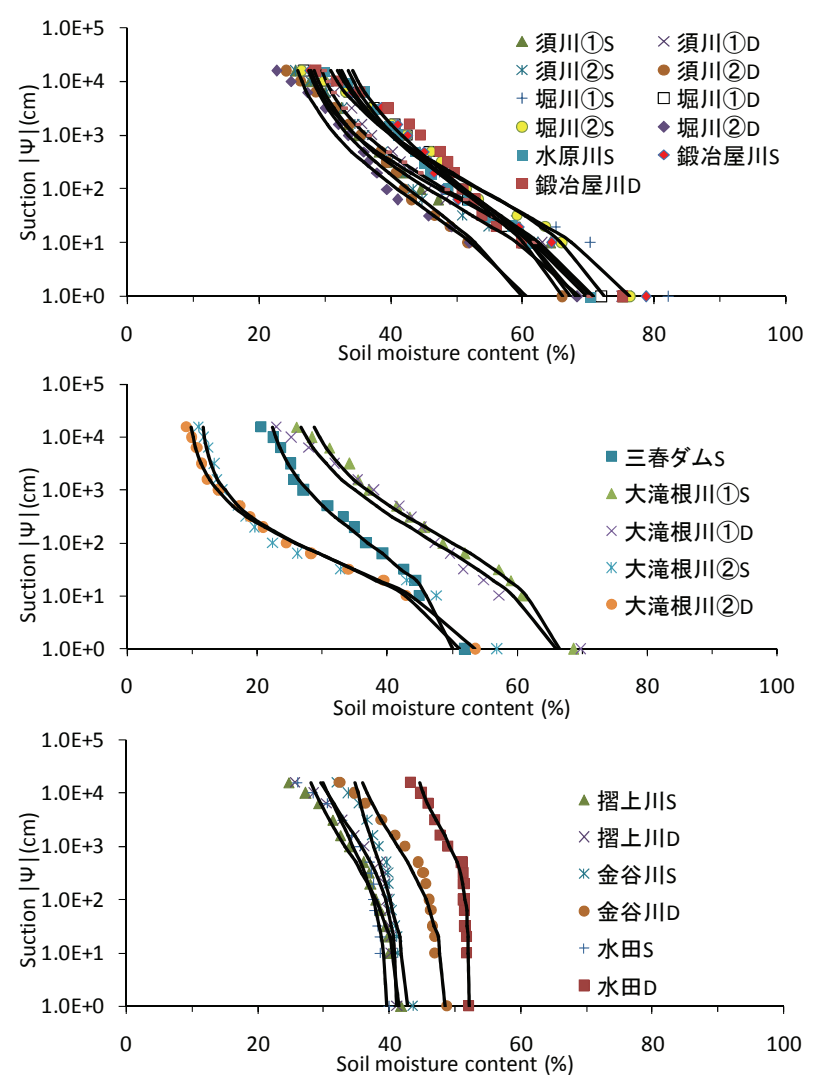

図-4 土䁃水分特性の実験結果と同定曲線

(S:採取深度約 $50 \mathrm{~cm}, \mathrm{D}: 100 \mathrm{~cm}$, (1)と(2)は採取地点が異なる)

市内の水田で採取した土壌の結果であるが、同じ西側で も上段とは明らかに異なる特性を示す。これらの特徵は 粗孔隙の少ないカべ状構造の土壌に見られる。。以上の 土壤の飽和透水係数を図-4のそれぞれについて整理した (表-3)。表-3の(1)〜 (4)は図-4の上段(1))、中段(2)、下段 (3)(4)に対応している。土培分類上は同じ森林土壌でも、 風化花崗岩上に形成された土㙵(2)の平均值は凝灰岩上の 土壤(3)よりも数オーダー高い透水性を有し、第四期火砕 岩地層上の土袞に比較的近いことがわかる。土壌は基岩 の風化作用と植生の双方の影響を受けて形成されるが、 基岩の影響がより強く現れていると考えられる。以上か ら、表層地質と土地利用(水田)に応じた土壤の不飽和特 性と飽和透水係数・空隙率を設定して用いた(表-4)。ま た、鉛直不飽和浸透解析を行う表層土壌の厚さには土壤 採取時に行った現地貫入試験結果からおよそ妥当と考え られる值（2３m）を用い、流域全体一律と仮定した。

\section{（3）表層土袞と帯水層のモデル化とパラメータ設定}

WEPモデルでは表層土懔内の不飽和鉛直浸透を多層土 㙵に対するGreen AmptモデルとDarcy則を用いて解析す る ${ }^{4)}$ 。表層土㙵の下部には不圧帯水層を設け、さらにそ の下に基岩を想定する(図-5)。帯水層では準一様流の仮 定に基づき地下水の側方流れを解析寸る。帯水層より鉛 直下方への浸透量は基岩の種類に応じて設定する透水係 数に応じて求める。

山地域と盆地域の地下水流動（山地域では山腹斜面の 
表-3 表層土壊の透水係数と空隙率

\begin{tabular}{|c|c|c|}
\hline 採取地の地質分類 & 飽和透水係数 $(\mathrm{cm} / \mathrm{s})$ & 空隙率 $(\%)$ \\
\hline (1)第凹期更新世安 & $1.95 \times 10^{-3}$ & 74.1 \\
\hline 山岩溶岩 - 火砕岩 & $2.30 \times 10^{-4} \sim 1.63 \times 10^{-2}$ & $67.1 \sim 81.9$ \\
\hline \multirow{2}{*}{ (2)花崗閃緑岩 } & $1.64 \times 10^{-3}$ & 61.7 \\
\hline & $6.50 \times 10^{-4} \sim 3.75 \times 10^{-3}$ & $53.2 \sim 70.2$ \\
\hline \multirow{2}{*}{ (3)凝灭岩 } & $3.73 \times 10^{-7}$ & 55.0 \\
\hline & $1.39 \times 10^{-7} \sim 1.41 \times 10^{-6}$ & $52.3 \sim 59.7$ \\
\hline \multirow{2}{*}{ (4)水田 } & $7.62 \times 10^{-8}$ & 46.6 \\
\hline & $3.61 \times 10^{-8} \sim 1.61 \times 10^{-7}$ & $40.0 \sim 53.2$ \\
\hline
\end{tabular}

数值の上段は平均、下段は範井。透水係数は対数平均。

表-4 表層地質・土地利用に応じた土鍄のパラメータ

\begin{tabular}{|l|c|}
\hline 表層地質または土地利用 & パラメータ分類 \\
\hline 火山砕屑物, 石英安山岩, 礫, 軽石等 & (1) \\
\hline 泥·砂·礫, 花崗岩, 火山角礫岩, 黒色片岩等 & (2) \\
\hline 凝灭岩, 砂岩, 硯岩, 泥岩等 & (3) \\
\hline 水田 & (4) \\
\hline
\end{tabular}

※以上の地質分類で流域全体の $95 \%$ 占める。

飽和側方流）の解析には、地下带水層の地質構造（層 序) 、厚さ、透水係数、比産出率、貯留係数の情報が必 要となる。これらのうち、層序と厚さの空間分布をモデ ルに与えるため、既往調査 ${ }^{7}$ の柱状図に基づき、流域内 の合計986地点におけるボーリングデータの深度別地質 分類を数值データ化し、このデータを補間して用いた (図-6)。ただし、基底面に達しないボーリングデータも 含まれため、福島盆地と郡山盆地の基底面標高には別途 作られたデータを用( Ł $^{8)}$ 。ボーリングデータ及び既存 の地質図等より、福島盆地や郡山盆地では明確な被圧帯 水層が見られなかったため、ボーリングデータから得ら れた層序情報は不圧帯水層の厚さ及び透水係数の推定に 利用した。帯水層の透水係数は各ボーリング地点におけ る地質別の層厚データと予め定めた地質別の透水係数と から加重平均により算出した值を空間的に補間して求め た(図-6)。なお、ここで求めた透水係数の值はモデルに よる河川流量の再現性を確認しながら補正した。基岩の 透水係数は文献 4 を参考に $1.0 \times 10^{-6} \sim 10^{-8} \mathrm{~m} / \mathrm{s}$ をえた。

\section{（4）気象特性と流出・利水情報のモデル化}

降水量、風速、日照時間、気温、相対湿度の空間分布 はティーセン法に基づき与えた。ただし、阿武隈川流域 の降水量に標高依存性が確認されたことから、計算格子 ごとに降水量の標高補正を行った。同様に気温について も気温減率 $0.65^{\circ} \mathrm{C} / 100 \mathrm{~m}$ で補正した。冬期には降雪があ ることから、融雪モデルとしてディグリーディ法を組み 込み、融雪量 $M(\mathrm{~mm} / \mathrm{day})$ を $M=M_{f}\left(T_{i}-T_{b}\right)$ で表した。こ こに、 $M_{f}$ : 融雪係数 $\left(1 \mathrm{~mm} /{ }^{\circ} \mathrm{C} /\right.$ day $) 、 T_{i}$ : 日平均気温 $\left({ }^{\circ} \mathrm{C}\right) 、$

$T_{b}$ : 基準温度 $\left(0^{\circ} \mathrm{C}\right)$ である。積雪量は降水量と気温から推

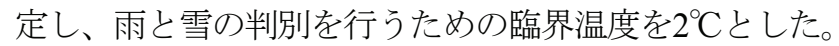

阿武隈川本川の粗度係数には河川整備計画にも用いら れた推定值 $(n=0.022 \sim 0.037)$ を河道区間別に与えた。支 川の下流部では本川粗度係数の平均值 $(n=0.033)$ を用いた。 Kinematic Wave法を用いた表面流解析では、等価粗度に 森林 $0.1 \sim 0.15$ 、草地 $\cdot$ 農地 0.03 、水田 0.05 、裸地 0.02 、都

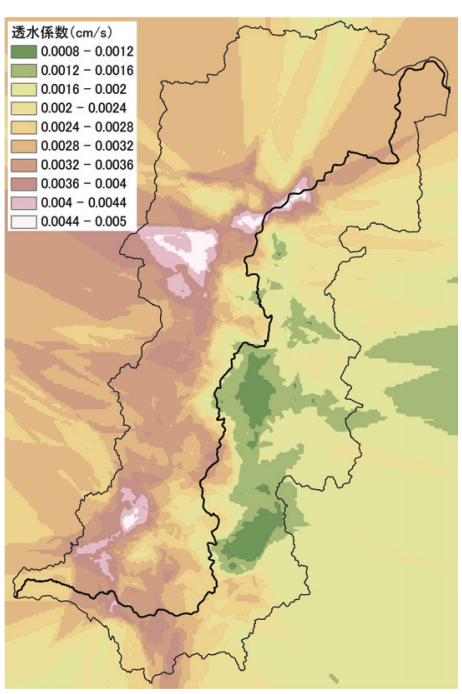

図-6 帯水層の厚さ(左)と透水係数の空間分布(右)

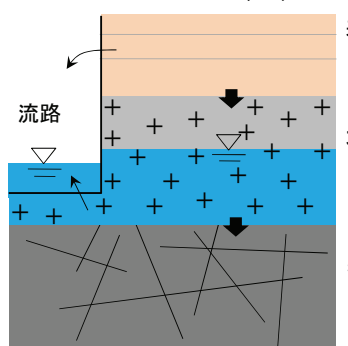

表層土(3層)

不飽和鉛直浸透モデルを適用。物理特性 厚さは実験及び現地調査結果に基づく

\section{不圧帯水層}

厚さはボーリングデータに基づく。準一様

流の仮定に基づく二次元地下水流モデル

基岩(花崗岩亀裂)

飽和透水係数に基づき不圧帯水層から の鉛直浸透量を与える。

図-5＼cjkstart地下水流れと河川水との交流のモデル概念

市 0.02 、水面 0.01 を与え、土地利用割合に応じた加重平 均して用いた。治水ダムのうち、三春ダム及び堀川ダム の貯水位一貯水量関係、貯水位一放流量関係、操作ルー ルを入手の上、ダムによる洪水制御モデルを組み込んだ。 都市用水使用量は300 lit./人・日、水田灌醌の純用水量 は代掻き期、普通期でそれぞれ $200 \mathrm{~m}^{3} / \mathrm{ha} 、 160 \mathrm{~m}^{3} / \mathrm{ha}$ とし た。安積疏水等の流域外導水による灌溉地域(約 $145 \mathrm{~km}^{2}$ ) では猪苗代湖からの日取水量実績データを用いて灌睰水 量の日々の変動をモデル上で考慮した。それ以外の地域 では灌泊用水は全量、河川から取水すると設定した。

\section{4. 数值解析}

\section{（1）数值解析の条件設定}

水循環の再現計算は2002 2004年を対象とした (表-5)。 この期間で最大の洪水は2002年7月11日に台風6号の影響 で発生し、流域平均2日雨量約 $220 \mathrm{~mm}$ 、実績流量は本川

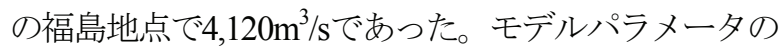
キャリブレーションは流域の地質、土㖶、土地利用、地 形等の特徵が異なり、かつ流量データが入手できた6支 流域を対象に行った(表-6、図-1,7)。地下水位や土䁃水 分量の初期条件の影響を取り除くためのウォームアップ 計算を6年間分行った後、表-5の3年間分を解析した。

\section{（2）パラメータの感度分析}

本モデルには多数のパラメータ4),5)方用いられているた 
表-5 水循環解析の条件

\begin{tabular}{|l|l|}
\hline \multicolumn{1}{|c|}{ 項目 } & \multicolumn{1}{|c|}{ 内容 } \\
\hline 解析期間/時間刻み & $2002 / 1 / 1-2004 / 12 / 31,1$ 時間(地表流·河道流10分) \\
\hline 河川流量比較地点 & 6支流域の流量観測地点 \\
\hline
\end{tabular}

表-6 パラメータ検証対象の支流域の概要

\begin{tabular}{|c|c|c|c|c|}
\hline 流域名 & $\begin{array}{c}\text { 集水面積 } \\
\left(\mathrm{km}^{2}\right)\end{array}$ & $\begin{array}{l}\text { 土地利用の } \\
\text { 特徵* }\end{array}$ & 主たる表層地質** & $\begin{array}{l}\text { 標高*** } \\
\text { (T.P.m) }\end{array}$ \\
\hline 広瀬川 & 266 & 森林(65\%) & $\begin{array}{l}\text { 花崗岩 }(65 \%) \cdot \text { 石英安山岩 } \\
\text { 等 }\end{array}$ & $\begin{array}{c}40-826 \\
(294)\end{array}$ \\
\hline 荒川 & 185 & 森林(65\%) & $\begin{array}{l}\text { 第四紀 / 石英安山岩・火山 } \\
\text { 砕屑物 }(68 \%) \cdot \text { 礫等 }\end{array}$ & $\begin{array}{c}\text { 64-1924 } \\
(738)\end{array}$ \\
\hline $\begin{array}{l}\text { 釈迦 } \\
\text { 堂川 }\end{array}$ & 305 & 水田(21\%) & $\begin{array}{l}\text { 新第三紀・第四紀 / } \\
\text { 軽石・礫(76\%)等 }\end{array}$ & $\begin{array}{c}235-937 \\
(400)\end{array}$ \\
\hline $\begin{array}{l}\text { 大滝 } \\
\text { 根川 }\end{array}$ & 384 & 畑地(24\%) & 花崗岩(81\%)等 & $\begin{array}{c}223-1126 \\
(470)\end{array}$ \\
\hline 移川 & 276 & 畑地 (29\%) & 花崗岩(90\%)等 & $\begin{array}{c}185-991 \\
(481)\end{array}$ \\
\hline $\begin{array}{l}\text { 本川 } \\
\text { 上流 }\end{array}$ & 303 & 水田 $(19 \%)$ & $\begin{array}{l}\text { 第四紀／軽石・磼(61\%) } \\
\text { • 火山砕屑物等 }\end{array}$ & $\begin{array}{l}267-1853 \\
(510)\end{array}$ \\
\hline
\end{tabular}

*他流域に比較して割合の高い土地利用(カッコ内は流域内での割合)

**国土数值情報に基づく。カッコ内はその前に記した全地質の占有率

***流域内の最小標高一最大標高 (平均值) の順に記載

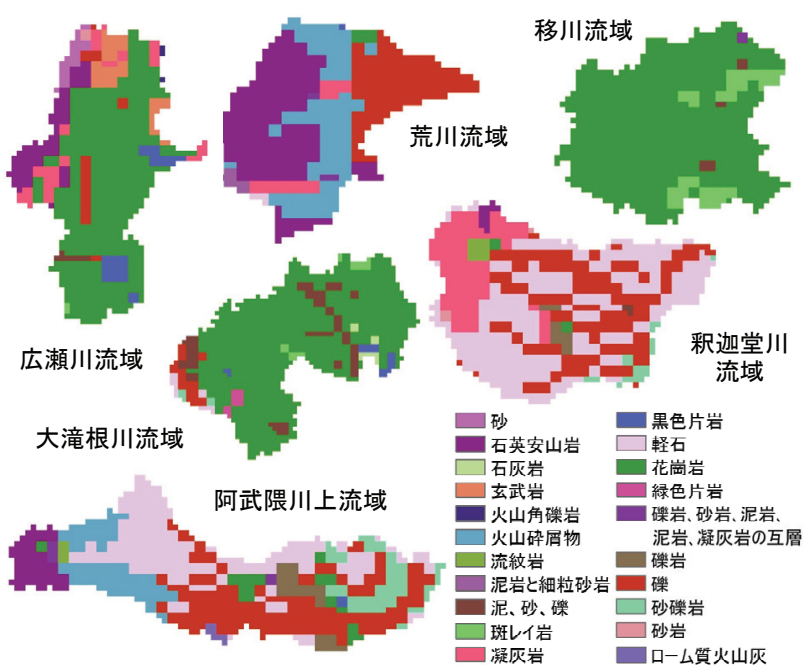

図-7 対象流域の表層地質分布

め、それらの内で比較的感度の高い表-7のパラメータを 対象に予備的に感度分析を行った。感度分析では、複数 個のパラメータのうち、ただ1つのパラメータの值のみ を変化させ、出力結果の変化からそのパラメータの感度 を調べた。各パラメータの感度は他のパラメータの值に も影響され得るが、基本となるデフォルトのパラメータ セットは測定值や実績值に基づいて定めたものを使用し た(表-7)。

感度分析の結果、帯水層の透水係数、比産出率、帯水 層厚、河床透水係数が他に比べて洪水流量や基底流量に 比較的大きな影響を及ぼしていた。これらの感度には及 ばないが、表層土㙵厚、土壌透水係数、粗度係数等も計 算結果に中程度の影響を及ぼすパラメータであった。そ こで、これらパラメータの標準化を次のように検討した。

\section{（3）パラメータセットの同定と再現結果}

分布物理型モデルは水文現象の物理法則に基づくこと から、モデルパラメータ值は原理的には現地計測、室内
表-7 感度分析と補正の対象パラメータ及び補正結果

\begin{tabular}{|l|l|c|c|c|c|}
\hline \multicolumn{1}{|c|}{ パラメータ } & デフォルト値 & 荒川 & 移川 & $\mathrm{W}$ & $\mathrm{E}$ \\
\hline 畑地の最大湛水深 & $30 \mathrm{~mm}$ (文献5) & 1.7 & 0.7 & 1.7 & 0.3 \\
水田の最大湛水深 & $100 \mathrm{~mm}$ (現地情報) & 1 & 1 & 1 & 1 \\
第1,2,3層の土壌厚さ & $20,40,140 \mathrm{~cm}$ & 1 & 1 & 1 & 1 \\
表面流等価粗度 & 本文3(4) 文献 9 & 1 & 0.8 & 1 & 0.8 \\
土壤飽和透水係数 & 表-3参照 & 1 & 1 & 1 & 1 \\
。不圧帯水層の厚さ & 図-5参照 & 1 & 1 & 1 & 1 \\
。不圧帯水層の比産出率 & 0.02 (文献5) & 1 & 2 & 1.5 & 1 \\
。不圧帯水層の透水係数 & 図-5参照 & 1 & 2 & 1.5 & 1 \\
。河床の透水係数 & 上記に同じ & 1 & 2 & 1.5 & 1 \\
\hline
\end{tabular}

補正結果 (右4列) はデフォルト值に対する倍率を表す。

右2列は西側流域 $(\mathrm{W})$ と東側流域(E)に対する補正倍率を表す。

実験、既往の適用事例などに基づき合理性・物理的根拠 を有する範囲で与えることができる。しかし、現実には 物理パラメータにも不均一性・不確実性があり、また、 現地計測による同定が困難なパラメータもあるため、補 正(キャリブレーション)は必要不可欠と考えられる。そ こで、比較的感度の高かったパラメータ(表-7○)の補正 を河川流量の再現性を確認しながら行い、地質・土壤・ 土地利用の特徵に応じてどのようなパラメータの修正が 必要となるかを調べた。中程度の感度を有するパラメー 夕については基本的に実測や既往実績をもとに定めたが、 必要に応じて補正の対象とした。

図-8,9はデフォルト設定に補正を加えた後(表-7参照) の荒川と移川の再現計算結果である。荒川ではほぼデ フォルト設定で再現が可能であったが、花崗岩地質上に 広がる移川流域の場合、デフオルトでは洪水が過大な推 定結果になったため表-7に示した補正が必要であった。 補正したパラメータは不圧帯水層の透水係数と比産出率、 河床の透水係数などであり、図-6で示した不圧帯水層透 水係数の初期設定が本川東側の花崗岩域で低く見積られ ていたことを示している。同時に、風化花崗岩上の流域 における不圧地下水帯の役割が洪水・低水ともに重要で あることを示唆している。

図-10は荒川又は移川で適合性が確認されたパラメー 夕に対して必要に応じて再補正をして荒川、移川以外の 支川流域に適用した結果である。西側の釈迦堂川之阿武 隈川上流の流域では不圧帯水層の透水係数、比産出率、 河床の透水係数の倍率を 1.5 に修正し、他は荒川と同じ パラメータ設定で良好な再現結果が得られた。東側の広 瀬川は表面流等価粗度と畑地の最大湛水深を補正した以 外は全てデフォルト值で良好な再現結果が得られた。大 滝根川流域はいずれのパラメータ設定でも再現性に限界 が見られた(図-10)。勫迦堂川と阿武隈川上流では軽石や 礫が表層地質の主体をなしており(図-7)、このことが荒 川と異なる帯水層パラメータを必要とする原因と考えら れる。よって地質分類ごとの透水係数等のパラメータ設 定精度を上げれば補正を要しないパラメータ化が可能と 考えられる。また、東側河川流域の森林は小規模な里山 に多く、用水路等が整備されていることが粗度を小さく 寸る要因と考えられる。 

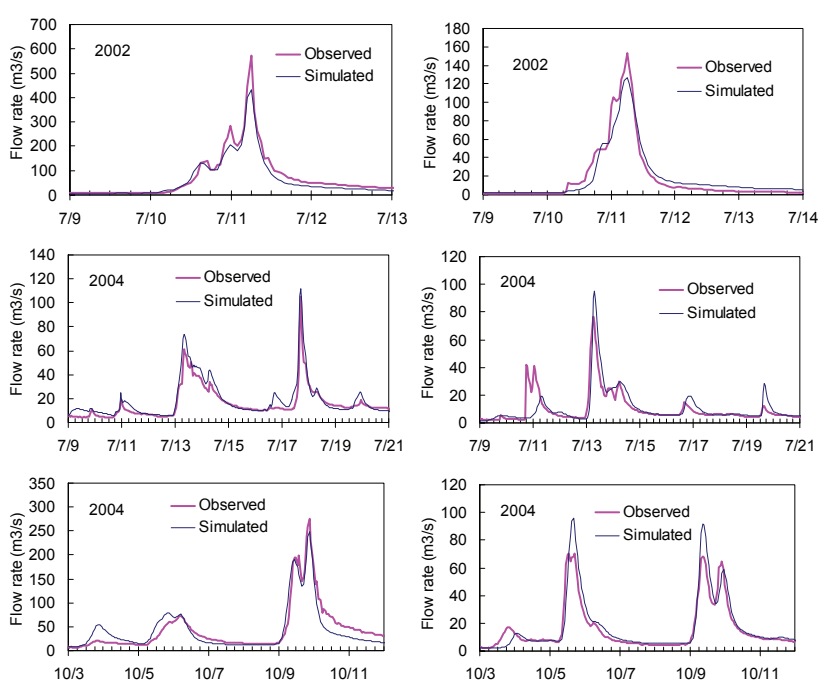

図-8 洪水の解析結果と実測值 (左 : 荒川、右 : 移川)
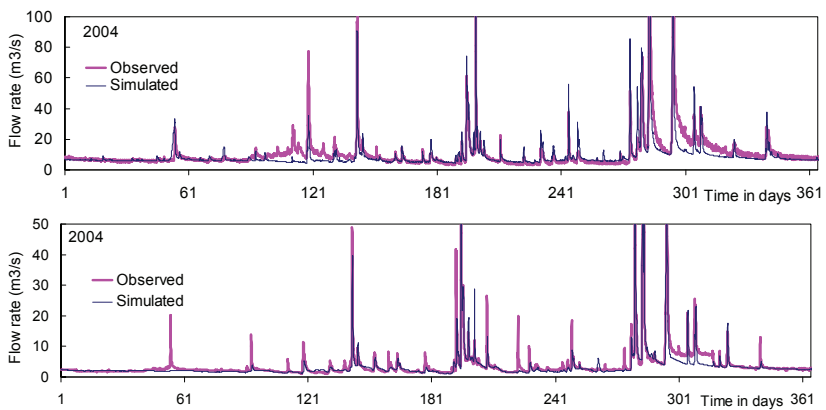

図-9 年間ハイドログラフの比較（上段 : 荒川、下段 : 移川）

以上の適用条件による解析結果の再現精度を表-8に示 す。大滝根川以外ではピーク流量、総流出量、ハイドロ グラフの適合度を表す指標の一つであるNash効率(NSE) のいずれも比較的高い值を示したが、大滝根川流域では 洪水時の適合性が良くなかった。これには洪水時におい てモデルで推定される以上に流出を抑制する作用が流域 水文過程に備わっている可能性が考えられる。

\section{5. 結論}

本研究では将来の流域環境変化が水循環に及ぼす影響 評価の信頼性向上並びに水文情報の乏しい流域の水循環 解析への利用を図るため、分布物理型水循環モデルにお いて地質・土壌・土地利用とその空間分布の違いをモデ ルパラメータに反映させる手法の提示と解析結果の適合 性検証を行った。今回の検討により、現地計測等から得 られた地質・土壤・土地利用のデフォルトパラメータに ある程度の補正要素を導入することで比較的良好に実測 值を再現できることがわかった。補正が必要となった理 由(流域条件の違い)も見当をつけることができた。モデ ルパラメータには空間スケールへの依存性があることが

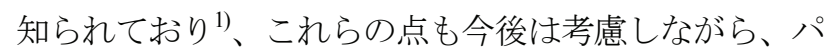
ラメータの一般化の検証を重ねることで多様な流域条件 に対するモデルの適用性や水文情報に乏しい流域での利 用可能性が高まるものと考えられる。
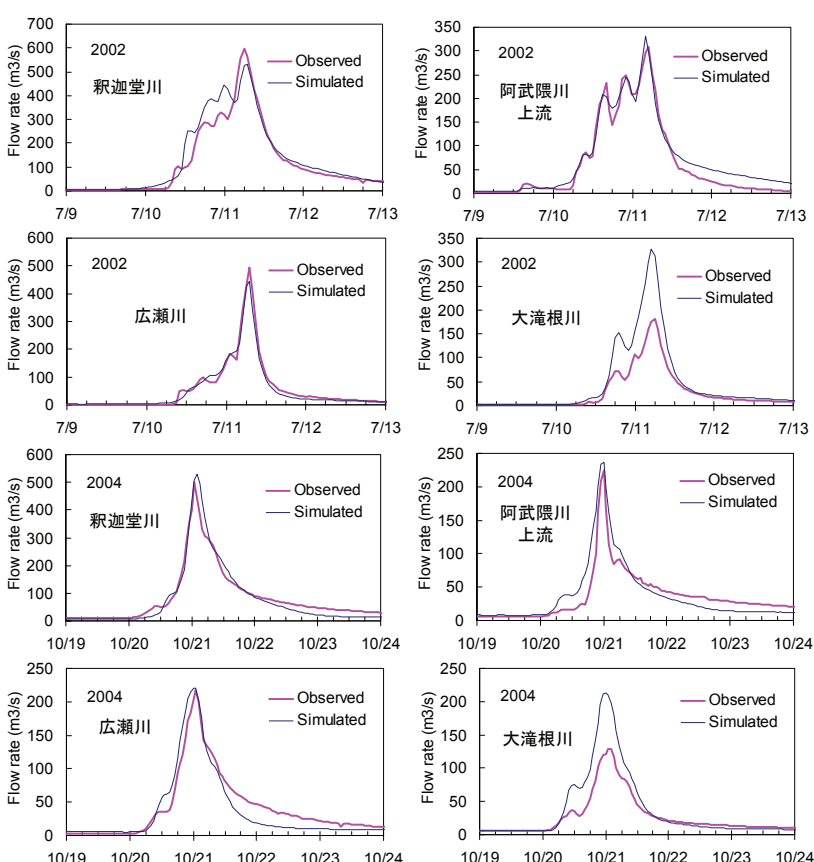

図-10４支川流域一の適用結果の例(2002.7, 2004.10)

表-8 補正後パラメータによる各流域の解析結果

\begin{tabular}{|c|c|r|r|r|r|}
\hline & \multirow{2}{*}{$\begin{array}{c}\text { NSE } \\
\text { (2004年) }\end{array}$} & \multicolumn{2}{|c|}{ ピーク流量 } & 総流出量 & 平水流量 \\
\cline { 3 - 5 } & $2002 / 7 / 11$ & $2004 / 10 / 21$ & (2004年) & (2004年) \\
\hline 荒 川 & 0.83 & -24.8 & -3.5 & -10.5 & -13.0 \\
\hline 移 川 & 0.82 & -17.2 & -11.3 & -10.4 & -13.1 \\
\hline 釈迦堂川 & 0.81 & -10.7 & 5.5 & 2.6 & -3.7 \\
\hline 阿武隈上流 & 0.81 & 7.2 & 4.9 & 10.8 & 23.6 \\
\hline 広 瀬 川 & 0.89 & -10.2 & 1.5 & 12.1 & 55.6 \\
\hline 大潼根川 & 0.11 & 81.5 & 65.4 & 23.6 & 6.4 \\
\hline
\end{tabular}

NSE: Nash-Sutcliffe Efficiency，他は(解析値一実測值) /実測值(\%)

謝辞：本研究は国土交通省国土技術政策総合研究所水資 源研究室・福島河川国道事務所の財政的支援を受けた。 データ入手や調査実施等では福島河川国道事務所、福島 大学学生諸氏の協力を得た。ここに記して謝意を示す。

\section{参考文献}

1)立川康人 : 流域水循環の数值モデルの進歩と今後の課題、 2002年度水工学に関する夏期研修会講義集Aコース、土木学 会水理委員会・海岸工学委員会、2002.9.

2)国土交通省河川局 : 阿武隈川河川整備基本方針、2004.1.

3)虫明功臣, 高橋裕, 安藤義久: 日本の山地河川の流況に及ぼす 流域の地質の効果, 土木学会論文報告集, 309, 51-62, 1981.

4)Jia, Y., G. Ni, Y. Kawahara, T. Suetsugi, Development of WEP model and its application to an urban watershed, Hydrological Processes, Vol.15, No.11, 2175-2194, 2001.

5)Jia, Y., T .Kinouchi, J. Yoshitani, Distributed hydrologic modeling in a partially urbanized agricultural watershed using water and energy transfer process model, Journal of Hydrologic Engineering, ASCE, Vol.10, No.4, 253-263, 2005.

6)塚本良則編 : 森林水文学、文永堂出版、1992.

7)福島県地質調査業協会, 福島県地盤・地質調査資料集, 1993.

8)柴崎直明 : 福島地下水盆・郡山地下水盆の予察的シミュレー ションモデルの構築と地下水観測網の検討，共生のシステム Vol.5, 103-113, 2007.3.

9)Kinouchi, T. and Musiake, K.: Simulating hydrological impact of environmental change in the Abukuma Watershed, Japan, 4th APHW Conference, 2008.11.

(2010. 9. 30受付) 